\title{
INTERNATIONAL SOCIO-ENVIRONMENTAL CONFERENCES AND AGREEMENTS: A THEMATIC REVIEW
}

\author{
Antonio Sergio Torres Penedo* \\ Vinícius Silva Pereira** \\ Gustavo Henrique Silva de Souza*** \\ Nilton Cesar Lima**** \\ Elvis Silveira-Martins ${ }^{* * * * *}$ \\ Talita Moscardini Ferreira Penedo ${ }^{* * * * * * *}$
}

\begin{abstract}
This article presents a theoretical analysis on international socioenvironmental conferences and agreements organized by the United Nations, which, concerned about climate change, biodiversity loss, among other environmental consequences, have resorted to international cooperation tools to seek ways to preserve the planet. The United Nations conferences were developed in order to promote the sustainable management and the overall commitment with the assumptions of more equitable development. Among the conferences and meetings, stand out Stockholm in 1972, the ECO-RIO in 1992, the Kyoto protocol in 1997, The Global Compact in 2000, The Millennium Development Goals in 2000, the Green Book in 2001, Johannesburg in 2002, The Equator Principles in 2003, Copenhagen in 2010. This study brings relevant considerations on innovative issues that covering the sustainable development and its consequences for the environment, taking into account the current context in which the world is passing away. Thus, we understood that, although the structural foundations of green marketing are essential in the scope of international socio-environmental conferences and agreements, a stronger awareness is necessary among the world's population, especially with regard to consumer culture.
\end{abstract}

Doutor em Engenharia de Produção pela Universidade Federal de São Carlos (UFSCAR); Docente Adjunto Universidade Federal de Uberlândia (UFU), Minas Gerais, Brasil; E-mail: astpenedo@yahoo.com.br

** Doutor em Administração pela Fundação Getúlio Vargas (FGV); Docente Adjunto da Faculdade de Gestão e Negócios (FAGEN) da Universidade Federal de Uberlândia (UFU), Minas Gerais, Brasil.

${ }^{* * *}$ Mestre em Psicologia (Comportamento Empreendedor) pela Universidade Federal de Alagoas (UFAL); Docente do Curso de Administração da Faculdade Raimundo Marinho (FRM), Campus Maceió, Brasil.

${ }^{* * * *}$ Doutor em Administração pela Universidade de São Paulo (USP); DocenteAdjunto II e Docente do Programa de Pós-graduação em Ciências Contábeis (PPGCC) da Faculdade de Ciências Contábeis da Universidade Federal de Uberlândia (UFU), Minas Gerais, Brasil.

Doutor em Administração e Turismo, Departamento de Administração e Turismo na Universidade Federal de Pelotas (UFPel), Pelotas (RS), Brasil.

${ }^{* * * * * *}$ Bacharel em Direito pela Faculdade de Ituverava Dr. Francisco Maeda (FAFRAM), Ituvevara (SP), Brasil. 
KEY WORDS: Agreements; Conferences; Environmental Responsibility; Socioenvironmental issues; United Nations.

\section{CONFERÊNCIAS E ACORDOS SOCIOAMBIENTAIS INTERNACIONAIS: UMA REVISÃO TEMÁTICA}

RESUMO: Este artigo apresenta uma análise teórica sobre as conferências e acordos socioambientais internacionais organizados pelas Nações Unidas que, preocupada com as mudanças climáticas, perda da biodiversidade, dentre outras consequências ambientais, têm recorrido a instrumentos de cooperação internacional para buscar formas de preservar o planeta. As conferências das Nações Unidas são desenvolvidas a fim de promover a gestão sustentável e o compromisso global com as premissas de um desenvolvimento mais equitativo. Dentre as conferências e acordos (reuniões), destacam-se Estocolmo em 1972, a ECO-RIO em 1992, o protocolo de Kyoto em 1997, o Pacto Global em 2000, os Objetivos de Desenvolvimento do Milênio em 2000, o Livro Verde em 2001, Johanesburgo em 2002, os Princípios do Equador em 2003 e Copenhagen em 2010. Este estudo traz relevantes considerações acerca das questões inovadoras que tratam do desenvolvimento sustentável e suas consequências para o meio ambiente, levando em conta o atual contexto em que o mundo passa. Assim, depreende-se que, embora as noções estruturantes do marketing verde sejam essenciais no escopo das conferências e acordos socioambientais internacionais, é preciso uma conscientização mais forte dentre a população mundial, especialmente no que diz respeito à cultura do consumo.

PALAVRAS-CHAVE: Acordos; Conferências; Nações Unidas; Questões socioambientais; Responsabilidade ambiental.

\section{INTRODUCTION}

Sustainability is a topic of great interest in the media, business community, government agencies, non-governmental organizations and civil society, due the structural possibilities for the organizational and production systems' evolution to improve the quality of life (QOL) of the population (PANCHAL; MOSCHANDREAS, 2015). Companies generate various forms of benefit to society, as technological advances, job creation, workforce training, development of a productive network, 
distribution of income and payment of taxes and wages, among others. However, many are also the damage caused by its activities, as manipulation and corruption of people and governments, creating a dependency relationship, depletion of natural resources and damage the environment (EPSTEIN; BUHOVAC, 2014; O'RIORDAN, 2014).

Considering a proactive and post-conventional level on the business ethics, there is a school of thought which advocates the need for companies to take an ethical stance towards society, expanding their role beyond purely economic objectives, in order to participate in community and environment in which it operates the most extensive way possible (DIAS, 2009; FRASER et al., 2006). This happens because they use up more resources difficult to measure or have prices assigned to people, financial, natural resources (renewable or not) and a whole structure of the society in which they operate. So have a greater responsibility towards society, as assumed from the beginning of its existence. Despite being a relatively recent idea, the demands from society are increasing. Corporate social responsibility includes all business and innovative relationships with the community where it operates, thus becoming a broader view of the business strategy should include the attendance of the "social function" of the company, by improving the quality of life in all its broader aspects and environmental protection. In this context, practices aimed at ensuring transparency, fairness in the distribution of earnings and sustainability are required (BENI, 2003; LIMA, 2003; BARBIERI et al., 2010).

In this regard, the following article presents - in a thematic review a theoretical analysis on international socio-environmental conferences and agreements organized by the United Nations, which, concerned about climate change, biodiversity loss, among other environmental consequences, have resorted to international cooperation tools to seek ways to preserve the planet. The United Nations conferences were developed in order to promote the sustainable management and the overall commitment with the assumptions of more equitable development. Among the conferences and meetings, stand out Stockholm in 1972, the ECO-RIO in 1992, the Kyoto protocol in 1997, The Global Compact in 2000, The Millennium Development Goals in 2000, Green Book in 2001, Johannesburg in 2002, The Equator Principles in 2003, Copenhagen in 2010. Since this discussion 
is of utmost importance for understand the results achieved and how much the thematic still needs to move forward, the study is justified in its extra-conceptual relevance.

\section{INTERNATIONAL SOCIO-ENVIRONMENTAL CONFERENCES AND AGREE- MENTS: THEMATIC REVIEW AND HISTORIC POSTULATES}

In the early 1970's, concerns related to climate change and quality of life of human beings began to gain ground on the world stage (TURNER, 1988). The observation about the limitations of the capitalist development model and the pressure with respect to environmental issues caused by it added to the social movements - in several countries - the discussion in society of the following problems: pollution, global warming, soil erosion, forest clearing, destruction of the ozone layer, civil liberties etc. (DIAS, 2009).

Front to these issues raised by social movements and due to environmental crisis that plagued the world in 1972, the Conference on Ecosystem was held in Stockholm, Sweden, yielding the concept of Sustainable Development that would consolidate 20 years later in the Ecosystem Symposium of the United Nations in 1992 (CAMARGO, 2003; SACHS, 1998). Environmental responsibility should include all of the company relationships with the communities where they operate including meeting the social function of property. In this context, practices aimed at ensuring transparency, fairness in the distribution of earnings and environmental protection should be required (EPSTEIN; BUHOVAC, 2014; O'RIORDAN, 2014).

The Club of Rome published in 1972 the book "Limits to Growth" with discussions on the environmental resources preservation of the water, air, soil, energy, due the waste accumulation and the environmental degradation. At the United Nation Conference dealing with Human Development in June 1972, in Stockholm, 113 countries committed to preserving the earth's ecosystem. The United Nations Development Programme to the terrestrial ecosystem, known by United Nations Environment Programme (UNEP), aims to encourage and promote care for the environment, informing and enabling countries to improve the quality of life of their populations (CAMARGO, 2002; SACHS, 1998). 
This Stockholm Declaration formed the basis for the Brazilian Constitution, which states: "Everyone has the right, essential to a healthy quality of life ecologically balanced terrestrial ecosystem, and both the Government's duty to defend and preserve it for present and future generations" (FIORILLO, 2007, p. 14).

In 1992, UNEP made a new meeting, the UN Conference on Sustainable Development, which primarily known as ECO-RIO 92. In that Conference were discussed issues relevant to sustainable development in developing countries, economic cooperation between the countries, and urgent creation of Agenda 21 (PASSOS, 2009).

According Milaré (2007), the ECO-RIO 92 was performed for countries to take cognizance of the need to reverse the increasing degradation of the terrestrial ecosystem, by considering the environmental variable measures focused on the compatibility of the development with public policy the preservation process environmental. The author states that the main objectives of the Conference were checking the global environmental situation, and establish forms of technology transfer, examine strategies for incorporating environmental criteria into the development process.

One of the main contributions of the ECO-RIO 92 was the Rio's Declaration on Development, an important document that proposes the Agenda 21, which establishes rules and principles for the promotion of economic and socioenvironmental development. Agenda 21 is a statement taken by States, though its signatories will develop environmental initiatives (PASSOS, 2009). Among its recommendations are the economic and socio-environmental dimensions to combat poverty and changing forms of consumption; appropriate use of environmental resources such as combating deforestation, encouragement of sustainable agriculture, safe management of hazardous wastes and protection of water resources, defended by several lines of thought worldwide (ROBERTSON et al., 2008).

The ECO-RIO 92 agreement to reduce the release of greenhouse gases that cause global warming known as the Convention on Climate Change gases was proposed. Initially 154 countries were signatories, and the Convention entered into force in 1994. In Berlin, Germany, was made the first Conference of the participating countries of the Convention (GONÇALVES, 2005). 
In December 1997, a review conference on climate change was held in Kyoto, Japan, which approved the so-called "Kyoto Protocol", which aimed to contain the destruction process of the living conditions of the land and degraded parts by basic guidelines firmed by this protocol (O'NEILL; OPPENHEIMER, 2002). The Protocol was signed on March 16, 1998, by 55 countries that were in the Convention, including the countries responsible for $55 \%$ of total emissions of carbon dioxide (GONÇALVES, 2005).

With the agreement countries pledged to reduce releases of greenhouse gases by at least $5 \%$ below 1990 levels by 2012 . Moreover, it was signed the transfer of financial resources from developed countries to other developing countries, for sustainable environmental development in these countries more secure foundations.

Under the Kyoto Protocol the less economically advanced countries should benefit from financial resources from developed countries. However, these funds must be used in technology in reducing emissions of harmful terrestrial ecosystem gases (SOUZA-LIMA, 2004).

For Souza and Miller (2004), among the numerous types of Clean Development Mechanisms (CDM) that can be developed, it is possible mention:

1. Capture of landfill gas;

2. Treatment of swine waste and reuse of biogas;

3. Fuel switching;

4. Generation of energy from renewable sources;

5. Composting of municipal solid waste;

6. Methane generation from organic waste (bio-gasification);

7. Pyrolysis of waste.

The Kyoto Protocol is a way for countries to invest in afforestation and reforestation (GONÇALVES, 2005), and strengthen the energetic reform by the use of renewable energy (GOLDEMBERG, 2009), promoting the recovery of carbon emissions sectors. Based on the Kyoto Protocol, carbon neutralization is a practical and legitimate action for socio-environmental responsibility stimulated by the United Nations Global Compact, a posteriori (CETINDAMAR, 2007; WILLIAMS, 2004). 
In early 2000, the then General Secretary of the United Nations (UN), Kofi Annan, launched the Global Compact aiming to mobilize the community to adopt in their business activities in environmental areas fundamental values, human rights and the combating corruption (UNDP, 2010).

The Global Compact is a voluntary initiative that aims to provide standards and principles in the pursuit of sustainable environmental development. Also performs a complement to the sustainability of the organizations activities, it was also used as the basis for the creation of ISO 26.000, which deals with the standardization of environmental responsibility.

Even with predominating organizations as signatories to the agreement, the Pact allows interested nonprofit may also sign the pledge. In Brazil, cities, nongovernmental organizations (NGOs), public sector unions and research institutions have adopted the Global Compact. The country being responsible for captaining organizations and their representatives was the ETHOS Institute. In June 2009, Brazil had 338 institutions, organizations with and without considering business activities, signatories of the Pact (UNDP, 2010).

Thus, the Global Compact is to encourage organizations to adopt environmental policies. This pact promotes dialogue between institutions, United Nations agencies, NGOs, trade unions and representatives of civil society for the development of an inclusive world market, aiming to include social and environmental responsibility in the process of globalization (UNDP, 2010).

To achieve the goal of sustainable environmental development, the United Nations seek the cooperation of international organizations with the adoption of the principles of human rights, labor and ecosystem. Despite the Global Compact to be a propellant for the sustainability, it is not intended to be a code of conduct. The Pact aims to promote sustainable human development, giving priority to long and healthy life with accessibility to decent standard of living (CETINDAMAR, 2007; WILLIAMS, 2004).

The Global Compact has ten proposals being established in its creation and nine other included later. All are related to statements, as Rio Declaration on Environment, Universal Human Rights, International Labour Organization, Fundamental Principles and Rights at Work and Development and the United Nations Convention (UNDP, 2010). 
This Pact, created by the United Nations Organizations, believes that business organizations are the main exacerbating economic growth and/or financially. So, should have the responsibility to promote sustainable economic development of the society in which they interact. Thus, the interests of the various sectors involved in society (stakeholders) should be respected and considered in all activities and functioning of institutions, whether corporate or not.

The Pact serves to align policies and practices internationally recognized as the promoters of environmental improvements throughout society. Thus, its principles attempt to reproduce the consistent goals of human rights, of labor rights, of environmental protection and of anti-corruption.

In Table 1 the principles and proposals of the United Nations Global Compact can be observed.

Table 1. Principles and Proposals of the United Nations Global Compact

\begin{tabular}{|c|c|} 
Principles & Proposals \\
\hline $\begin{array}{c}\text { Human Rights } \\
\text { Principles }\end{array}$ & Respect and protect human rights \\
& Prevent human rights violations \\
\hline $\begin{array}{c}\text { Principles of } \\
\text { Rights at Work }\end{array}$ & Abolish forced labor \\
\hline $\begin{array}{c}\text { Principles of } \\
\text { Environmental } \\
\text { Protection }\end{array}$ & Abolition of child labor \\
\hline $\begin{array}{c}\text { Principle against } \\
\text { Corruption }\end{array}$ & Work against corruption in all its forms (including extortion and bribery) \\
\hline
\end{tabular}

Source: Adapted from United Nations Development Programme (UNDP, 2010).

The Principles of Human Rights represents the two initial proposals. The first proposal suggests that organizations support and respect the protection of internationally recognized human rights worldwide. The second proposal certifies 
that organizations are not complicit in human rights abuses. The three areas of the Global Compact in respect to human rights are:

- The protection of life and safety;

- Individual rights and political freedoms, freedom of expression, privacy, religion and association;

- Economic, social and cultural rights, establishment of decent standard of living considering the food, housing, health, education, fair pay, leisure and rest.

The following four proposals refer to the Principles of Rights at Work. The first proposal of this principle shows the need to uphold the freedom of association and recognize the right to collective bargaining. The next proposal aims to eliminate all forms of forced or compulsory labor. The other two proposals address the effective abolition of child labor and the elimination of all discrimination at work is of origin, race, gender, creed and religion.

The defense of the terrestrial ecosystem is treated in the Principles of Environmental Protection. The first proposal of this principle, establishing the preventive approach of business activities. The next two proposals define initiatives to promote environmental responsibility and encourage the development and diffusion of clean environmental technologies. The adoption of the Global Compact has a preventive and not corrective nature, joining efforts in the management of the product life cycle.

Finally, the last proposal, which is in Principle against Corruption, provides that organizations should work against corruption in all its forms, including extortion and bribery. This principle aims to strengthen sustainable development.

As organizations will be involved in the commitment of adoption of these principles, they contribute in creating a more equitable society in the environmental aspect beyond the economic.

Thus, the Global Compact should be viewed with a mechanism of free membership by civil society institutions. Those who adhere to the Pact must accept the commitment to implement the ten proposals in its operations and account for 
the progress made in its implementation to all stakeholders through periodic reports prepared by organizations (UNDP, 2010).

Specifically in Brazil, the Global Compact influenced many companies to social responsibility. Nevertheless, the major problem in the Brazilian context is how companies are implementing the Global Compact guidelines, especially by the lack of evaluation mechanisms. Basically, Brazilian companies do not disclose their social responsibility actions explicitly and clearly. That is, companies affirm that have programs and social actions with employees and communities with predominantly social feature, however, fail to relate these actions with Global Compact principles (OLIVEIRA et al., 2008).

The organizations participants of the Global Compact were mobilized to promote an agenda of specific objectives for 2000s, which later became the Millennium Development Goals (MDGs) under the leadership from United Nations (UNDP, 2010). Thus, In New York, between 6 to 8 September 2000, 147 representatives of State and Government met to draft the United Nations Millennium Declaration. In the document were signed strategies and goals for overcoming the many problems faced by society as hunger and extreme poverty, lack of access to education, gender inequality, child mortality, spread of infectious diseases, environmental problems etc.

In this statement, eight objectives were established - called the Millennium Development Goals (MDGs) -, with stipulated targets and capable of being controlled, according to Table 2.

Table 2. The Millennium Development Goals (until 2015)

(Continua)

\begin{tabular}{|c|c|}
\hline Objectives & Goals \\
\hline $\begin{array}{c}\text { Improve Maternal } \\
\text { Health }\end{array}$ & Reduce by three quarters the maternal mortality ratio \\
\hline $\begin{array}{c}\text { Achieve Universal } \\
\text { Primary Education }\end{array}$ & Ensure that all children complete a full course of primary schooling \\
\hline
\end{tabular}


(Conclusão)

\begin{tabular}{|c|c|}
\hline Objectives & Goals \\
\hline \multirow{2}{*}{$\begin{array}{l}\text { Eradicate Extreme } \\
\text { Poverty and Hunger }\end{array}$} & $\begin{array}{l}\text { Halve the proportion of people whose income is less than one U.S. dollar } \\
\text { per day }\end{array}$ \\
\hline & Halve the proportion of people who suffer from hunger \\
\hline $\begin{array}{l}\text { Combat Infectious } \\
\text { Diseases }\end{array}$ & Commit financial resources to combat the spread of contagious diseases \\
\hline \multirow{5}{*}{$\begin{array}{l}\text { Develop a Global } \\
\text { Partnership for } \\
\text { Development }\end{array}$} & Program a non-discriminatory multilateral trading and financial system \\
\hline & Treat the debt problems of developing countries \\
\hline & Allow young people to have a decent and productive work \\
\hline & Providing accessibility to essential medicines \\
\hline & Make available the benefits of new technologies \\
\hline \multirow{3}{*}{$\begin{array}{l}\text { Ensure Environmental } \\
\text { Sustainability }\end{array}$} & $\begin{array}{c}\text { Integrate the sustainable development principles into policies and } \\
\text { programs }\end{array}$ \\
\hline & Reduce the proportion of people without access to safe drinking water \\
\hline & By 2020 , significantly improve the lives of at least 100 million slum dweller \\
\hline $\begin{array}{l}\text { Promote Gender } \\
\text { Equality }\end{array}$ & $\begin{array}{l}\text { Eliminate gender disparity in primary and secondary education and at all } \\
\text { levels of education }\end{array}$ \\
\hline $\begin{array}{l}\text { Reduce Child } \\
\text { Mortality }\end{array}$ & Reduce by two thirds mortality of children under 5 years \\
\hline
\end{tabular}

Source: Adapted from United Nations Development Programme (UNDP, 2010).

Although the MDG initiative is one of the few resulting from international to establish clear goals and objectives and specific, cannot be said that when an individual goes on to win more than $\$ 1.00$ daily bodies, he is above the poverty line, as measure absolute financial resources disregarding cost of living is extremely complicated countries (UNDP, 2010). Since 2000, environmental organizations challenged financial institutions with advertising campaigns very aggressive profile highlighting some commercial banks as lenders of environmental and social risks (O'RIORDAN, 2014).

In Brazil, only in 2005 the United Nations offices organized a large mobilization campaign to create a space for public discussion on the Millennium 
Development Goals (MDGs). This mobilization helped the voice of the National Movement for Citizenship and Solidarity and contributed significantly for the Brazil invest in monitoring and evaluation of the indicators and objectives agreed upon at the United Nations Millennium Declaration in 2000 (UNDP, 2010).

After contributions from the Millennium Development Goals (MDGs), new proposals were created. In this regard, the "Green Book" was promulgated in July of 2001 by the Commission of the European Communities, noting that despite the existential reason organizations are making a profit, they must help in meeting environmental goals through mechanisms and initiatives of environmental responsibility. Thus, it is possible to have an inclusive approach, consistent with a long-term strategy that minimizes potential impacts of unknowns (STERLING, 2001).

The positive results of the environmental initiatives can improve working conditions and increase worker productivity. However, the criticism of the environmental initiatives of an organization can affect their products, their brands and image. With respect to environmental management organizations, a major challenge is the retention of talent. In this context, among the possible measures to be adopted may include lifelong learning; enhancement of internal members; communication; interpersonal balance; diversity of human resources; equality in relationships; profit sharing and job retention (EPSTEIN; BUHOVAC, 2014; O'RIORDAN, 2014).

Environmental management in reducing the consumption of resources, polluting emissions or waste production contributes to minimizing the environmental impact should occur. Certain institutions claim that a farm with less intensiveness is likely to result in an increase in profits and a competitive (O'NEILL; OPPENHEIMER, 2002; STERLING, 2001).

The "Green Book" was launched with the aim of promoting a debate on the concept of environmental responsibility of organizations and identify aspects that enable environmental development in Europe. Highlighting mainly that socially responsible behavior is the source of commercial successes and involves the management of behavior change, in which organizations tend to seek balanced commitments for all parties involved.

As a reaction of these campaigns, in October 2002 a meeting of executives of large financial conglomerates was organized by the International Finance Corporation 
(IFC) and ABN Amro Bank in order to discuss practical experiences and investments in environmental projects at emerging markets, in London. So the need to measure risk analyzes on large investments in emerging countries was agreed. In February 2003, a second meeting also occurred in London where the initial guidelines were agreed in the document known as "Principles of Greenwich" (AMALRIC, 2005).

In May 2003, in Dusseldorf, Germany, a third meeting discussing the "Principles of Greenwich" changed and adjusted their intentions definitively, assigning the name "Equator Principles", clearly representing a division occurred between the countries of the "North" and "South". After one month, six new financial institutions launched the rules of the "Equator Principles". The Equator Principles are a set of socio-environmental practices that must be performed in financing works with values above a minimum amount. The IFC was in expectation that the "Equator Principles" could be used as the default implementation of environmental issues related to the financing of works in various economic and/or financial sectors of society (O'SULLIVAN; O'DWYER, 2009).

The functioning of the proposal is based on the classification of environmental and social risks of all projects, with values above a minimum amount, which aims at financing banks, which meet the "Equator Principles". Have been, as an example, the following classifications: Projects classified as " $\mathrm{A}$ " represent low risk, "B" average risk and "C" very high risk. In each project with different degrees of risk, corresponding actions are required to ensure their classification minimizing their environmental and social risks in society. With pressures from NGOs, social movements and civil society, financial institutions should require the funded projects aspects of sustainability, including punitive and restrictive clauses in credit agreements to organizations that do not comply with the principles of minimization of risks agreed on "Equator Principles" (O'SULLIVAN; O'DWYER, 2009; RABELO; LIMA, 2009).

Even with the Equator Principles' guidance for not finance weapons and tobacco sectors, banks were funding directly or indirectly these sectors. Eschewing the analysis of the impacts of such loans, some institutions even claim that these activities, when legally organized, generate financial resources and sustaining many families; thus, cutting your credit can result in a reduction of the activity causing 
environmental imbalance in the communities that these sectors act as main thread. This narrow view of funding ends causing some resistance from society, in some cases, sees the actions to minimize environmental risk only profit as a catalyst for financial institutions (CONLEY; WILLIAMS, 2011; O'SULLIVAN; O'DWYER, 2009; WRIGHT; RWABIZAMBUGA, 2006).

In Brazil, the factors that promoted the implementation of the "Equator Principles" were the pressures of non-governmental organizations, international environmental movements and the search for financial institutions to use as propaganda the adherence to sustainability commitment (PAIVA, 2010; RABELO; LIMA, 2009; WAJNBERG; LEME, 2009).

In 2002, on the eve of the World Summit on Sustainable Development held in Johannesburg, South Africa, information on which $40 \%$ of the world population facing water shortages were disclosed; each year, 3 million people died of diseases caused by pollution; 90 million hectares of forests were destroyed in among other problems. The United Nations believed that encounter than 22,000 representatives from 193 countries were possible to recover the climate consensus. However, cooperation spirit turned into a lack of commitment from rich countries shoulder their responsibilities, especially in Brazil. It may be noted that due to lack of supervision and power global these punishment mechanisms, there are not sanctions to stop the noncompliance, so fitting, every government make them into laws to ensure its effectiveness (SOUZA; MILLER, 2004).

In 2003, the United Nations created the Principles for Responsible Investment (PRI), or Principles for Responsible Investment program. These principles summarize the commitment of major international institutional investors and market participants to direct investments in sustainable entrepreneurial projects. In April 2006, with the participation of Kofi Annan, the PRI has its official launch at the New York Stock Exchange, with the top 20 global investors. This process was coordinated by the Finance Initiative of the United Nations Programme for the terrestrial ecosystem (UNEP-FI), including the United Nations Global Compact. Its formulation had the help of many civil society representatives as financial organizations, governmental and non-governmental organizations and also experts from academia (UNDP, 2010).

The Principles for Responsible Investment (PRI) include social, environmental 
and governance criteria, or Environmental, Social and Corporate Governance (ESG), making them more sustainable international financial markets. The PRI seek to align investment practices with the goals and the Millennium Development Goals (MDGs) of the United Nations, thus contributing to a more stable and inclusive global economy (IDIS, 2010).

In early 2010, the Principles for Responsible Investment had 700 signatories with approximately $\$ 20$ trillion in assets. After four years of its official launch, the number of signatories has multiplied rapidly, showing a higher demand and interest of managers and institutional investors to apply resources more responsibly involving all stakeholders in society (IDIS, 2010).

The initiative for its establishment is based on the understanding that the credit fueled by financial institutions is the driver of the global economy and that their decisions should reflect criteria of social and environmental issues. Thus, the actions of funding organizations should be married with the objectives of any society committed to social and environmental criteria beyond economical in the long term.

In Copenhagen, Denmark, the United Nations Convention was held - the 15th Conference of the Parties (COP-15) Climate Change. The presidential election of Barack Obama in the U.S., the economic crisis and the scientific studies showing the environmental impacts of global warming did not change decisions at COP-15 in Copenhagen (FISHER, 2010; MCGREGOR, 2011).

Human activity is a major cause of global warming, and in fact, all sectors of the economy have contributed to catalyze the problem (REIS; CUNHA, 2006; SOUZA; MILLER, 2004). For the World Health Organization (WHO, 2015), between 1970 and 2008, there was an increase of environmental problems in Brazil, that resulted in about 1 million people with health ailments (as respiratory diseases and stress).

About that, the Copenhagen Climate Conference mobilized the world's population and leveraged the discussion of environmental problems caused by the environmental devastation of business activities worldwide. For the United Nations, the people need to mobilize now, or will arise even big problems for the planet, which, according to the organization, in 2050, half the world's population will live with lack of clean water. 


\section{FINAL REMARKS}

The aim of this study was analyze the international social-environmental conferences and agreements organized by the United Nations, regarding to conceptual aspects, advances and possibilities for the sustainable development. Therefore, we conducted a literature review on the main (most relevant) elements that covered the conferences and agreements held by the United Nations for the sustainability. From this, results show there are many issues following the United Nations prerogatives', especially for a sustainable life through the water and energy wastage, as well as less pollution, but only conferences and agreements are not the solution for the world problems', since academic studies (LEVY, 1997; O'NEILL; OPPENHEIMER, 2002; PEARCE; ATKINSON, 1993; TURNER, 1988) have been produced on the problematics that affected the planet.

Nevertheless, United Nations conferences enable the identification of global problems and the development of affirmative proposals - a significant event in terms of planning. Recapping, at the United Nations Conference in 1972, Stockholm, 113 countries committed to preserving the earth's ecosystem, hence bringing the concept of Sustainable Development that would be realized 20 years later at the Symposium of the United Nations Program for Ecosystem in 1992. In 1992, United Nations Environment Programme (UNEP) had a new meeting, the UN Conference on Sustainable Development, known as ECO-RIO 92. In December 1997, a conference on climate change was held in Kyoto, Japan, so-called "Kyoto Protocol", which aimed to suppress the action of destroying the living conditions of the land and degraded parts by basic guidelines signed by this protocol.

In early 2000, the Secretary-General of the United Nations, Kofi Annan, launched the Global Compact, aiming to mobilize the community to adopt in their business activities in environmental areas fundamental values, human rights and the fight against corruption. In July 2001, the "Green Book" was announced by the European Communities Commission, noting that despite the existential question of the organizations is the acquisition of profits, they need to assist in the implementation of social-environmental purposes through mechanisms and sustainable responsibility. 
In turn, the United Nations established the Principles for Responsible Investment (PRI) program in 2003. These principles summarize the agreement of major international institutional investors and market participants to direct investments in sustainable entrepreneurial projects. This allowed in 2010, in Copenhagen, the 15th Conference of the Parties (COP-15) to the United Nations Convention on Climate Change. From economic crisis, academic studies (FISHER, 2010; MCGREGOR, 2011; PARKER et al., 2012) demonstrating the environmental impacts of global warming did not transform the deliberations at COP-15 in Copenhagen. The Copenhagen Climate Conference mobilized the world's population and leveraged the contention environmental problems caused by environmental destruction of business activities worldwide.

With that, the greatest achievement was the focus of international nongovernmental organizations (NGOs), media and environmental movements on this topic. However, lack the collaboration spirit and thus is necessary commitment by rich countries that shoulder their responsibilities. We can be observed that, due to lack of supervision and global punishment, these mechanisms have no sanctions to curb the noncompliance, so fitting, every government make them into laws to ensure their implementation.

For example, water and energy are the central elements for the human survival. Nevertheless, they are becoming a scarce resource. The demands for water and energy exceed the supply, and this situation does not show signs of change (GOLDEMBERG, 2007; ROGERS, 2008; SOUZA et al., 2013). According Mankad and Tapsuwn (2011), the society is the key for the sustainable development and environmental attitudes promotion, demanding from the governments and organizations some urgently changes.

Because of that, the proactive actions from the United Nations are of utmost importance to the proposition of functionalist alternatives for sustainable development of the planet. Basically, the structural foundations of green marketing are essential in the scope of international socio-environmental conferences and agreements; however, a stronger awareness among the world's population is needed, especially with regard to consumer culture (DEVINE-WRIGTH; HOWES, 2010; LARSON; IBES; WHITE, 2011). 
Specifically in Brazil, there are several difficulties of implementing affirmative policies and socio-environmental actions due to dependence on government resources and lack of public awareness, which overloads NGOs' activities. Some authors (BARBIERI et al., 2010; NASCIMENTO; MENDONÇA; CUNHA, 2012) sighted sustainable innovation as an alternative for Brazil, as standards forms of use the water (intelligent systems of sewage treatment) and energy (renewable energy or energy-saving electronics). Nevertheless, according Passos (2009), Brazil has followed hardly the United Nations meetings, which shows a commitment to the sustainable development agenda.

So, this study proves to be a starting point for a more assertive discussion of socio-environmental issues. From what has been shown in this article, it is noted that there have been significant advances globally, but there are still many possibilities, especially into the technological innovations for the environment. The technological capacity associated with the organizational scope tends to lead the population to new ways of sustainability. Thus, the relevance of the following study is in raising important issues and in the historical postulate of conferences and agreements from the United Nations brought here, which propose structural changes in all sectors (economic, market, public, social and environmental), more specifically the changes should start by the global consumption model.

For future researches, we recommend that the practical and technical elements connected with the implementation of socio-environmental policy should be investigated. That is, since it is known the influence of international agreements for the emergence of positive actions to sustainable development, we must then think about the implementation of these actions and the difficulties faced by all stakeholders and organizations. Therefore, we encourage researches that add relevant considerations for sustainable growth as a way to get better possibilities for the quality of life of the world's population in the coming decades. In accordance with Fischer and Comini (2012, p. 363), "the more mature initiatives based on private-sector social investments and on corporate responsibility practices indicate that the concept of philanthropy has been left behind"; thus it is necessary that the people (civil society and entrepreneurs) give more value to socio-environmental issues. 


\section{REFERENCES}

AMALRIC, F. The equator principles. Finance \& Bien Commun, n. 22, p. 8-11, 2005.

BARBIERI, J. C.; VASCONCELOS, I. F. G.; ANDREASSI, T.; VASCONCELOS, F. C. Inovação e sustentabilidade: novos modelos e proposições. Revista de Administração de Empresas, v. 50, n. 2, p. 146-154, 2010.

BENI, M. C. Como certificar o turismo sustentável. Turismo em análise, v. 14, n. 2, p. 5-16, 2003.

CAMARGO, A. Governança para o século 21. In: TRIGUEIRO, A. (Org.). Meio ambiente no século 21: 21 especialistas falam da questão ambiental nas suas áreas de conhecimento. Rio de Janeiro: Sextante, 2003.

CAMARGO, A. L. B. As dimensões e os desafios do desenvolvimento sustentável: concepções, entraves e implicações à sociedade humana. 2002. 198 f. Dissertação (Mestrado em Engenharia de Produção) - Universidade Federal de Santa Catarina, Florianópolis, SC.

CETINDAMAR, D. Corporate social responsibility practices and environmentally responsible behavior: The case of the United Nations Global Compact. Journal of Business Ethics, v. 76, n. 2, p. 163-176, 2007.

CONLEY, J. M.; WILLIAMS, C. A. Global banks as global sustainability regulators? The Equator principles. Law \& Policy, v. 33, n. 4, p. 542-575, 2011.

DEVINE-WRIGTH, P.; HOWES, Y. Disruption to place attachment and the protection of restorative environments: a wind energy case study. Journal of Environmental Psychology, v. 30, n. 3, p. 271-280, 2010.

DIAS, R. Gestão ambiental: responsabilidade social e sustentabilidade. São Paulo: Atlas, 2009.

EPSTEIN, M. J.; BUHOVAC, A. R. Making sustainability work: Best practices in managing and measuring corporate social, environmental, and economic impacts. Oakland, CA: Berrett-Koehler Publishers, 2014. 
FIORILLO, C. A. P. Curso de direito ambiental brasileiro. 8. ed. São Paulo: Saraiva, 2007.

FISHER, D. R. COP-15 in Copenhagen: How the merging of movements left civil society out in the cold. Global Environmental Politics, v. 10, n. 2, p. 11-17, 2010.

FISCHER, R. M.; COMINI, G. Sustainable development: from responsibility to entrepreneurship. Revista de Administração, São Paulo, v. 47, n. 3, p. 363-369, 2012.

FRASER, E. D. G.; DOUGILL, A. J.; MABEE, W. E.; REED, M.; McALPINE, P. Bottom up and top down: Analysis of participatory processes for sustainability indicator identification as a pathway to community empowerment and sustainable environmental management. Journal of Environmental Management, v. 78, n. 2, p. 114-127, 2006.

GOLDEMBERG, J. Ethanol for a sustainable energy future. Science, v. 315, n. 5813, p. 808-810, 2007.

GOLDEMBERG, J. Biomassa e energia. Química Nova, v. 32, n. 3, p. 582-587, 2009.

GONÇALVES, D. B. Mar de cana, deserto verde? Dilemas do desenvolvimento sustentável na produção canavieira paulista. 2005. 256f. Tese (Doutorado em Engenharia de Produção) - Universidade Federal de São Carlos, São Carlos, SP.

INSTITUTE FOR THE DEVELOPMENT OF SOCIAL INVESTMENT - IDIS. 2010. Available at: < http://www.idis.org.br > Accessed in: June 30, 2015.

LARSON, K. L.; IBES, D. C.; WHITE, D. D. Gendered perspective about water risks and policy strategies: a tripartite conceptual approach. Environment and Behavior, v. 43, n. 3, p. 415-438, 2011.

LEVY, D. L. Environmental management as political sustainability. Organization \& Environment, v. 10, n. 2, p. 126-147, 1997.

LIMA, G. F. C. Questão ambiental e educação: contribuições para o debate. Ambiente \& Sociedade, v. 2, n. 5, p.135-153, 1999. 
LIMA, G. F. C. O discurso da sustentabilidade e suas implicações para a educação. Ambiente \& Sociedade, v. 6, n. 2, p. 99-119, 2003.

MANKAD, A.; TAPSUWAN, S. Review of socio-economic drivers of community acceptance and adoption of decentralized water systems. Journal of Environmental Management, v. 92, n. 3, p. 380-391, 2011.

MCGREGOR, I. M. Disenfranchisement of countries and civil society at COP-15 in Copenhagen. Global Environmental Politics, v. 11, n. 1, p. 1-7, 2011.

MILARÉ, E. Direito do ambiente: a gestão ambiental em foco. 5. ed. São Paulo: Revista dos Tribunais, 2007.

NASCIMENTO, T. C.; MENDONÇA, A. T. B. de; CUNHA, S. K. da. Inovação e sustentabilidade na produção de energia: o caso do sistema setorial de energia eólica no Brasil. Cadernos EBAPE.BR, v. 10, n. 3, pp. 630-651, 2012.

O'NEILL, B. C.; OPPENHEIMER, M. Dangerous climate impacts and the Kyoto Protocol. Science, v. 296, n. 5575, p. 1971-1972, 2002.

OLIVEIRA, J. A. P. et al. A implementação do pacto global pelas empresas do Paraná. Revista de Gestão Social e Ambiental, v. 2, n. 3, p. 92-110, 2008.

O'RIORDAN, T. Environmental science for environmental management. London: Routledge, 2014.

O'SULLIVAN, N.; O'DWYER, B. Stakeholder perspectives on a financial sector legitimation process: The case of NGOs and the Equator Principles. Accounting, Auditing \& Accountability Journal, v. 22, n. 4, p. 553-587, 2009.

PAIVA, A. C. R. As atividades bancária e empresarial e o desenvolvimento sustentável. Revista de Administração, São Paulo, v. 45, n. 3, p. 297-304, 2010.

PANCHAL, A. P.; MOSCHANDREAS, D. J. Public literacy on sustainable development. International Journal of Environment and Sustainable Development, v. 14, n. 1, p. 71-88, 2015. 
PARKER, C. F.; KARLSSON, C.; HJERPE, M.; LINNÉR, B. O. Fragmented climate change leadership: making sense of the ambiguous outcome of COP-15. Environmental Politics, v. 21, n. 2, p. 268-286, 2012.

PASSOS, P. N. C. A conferência de Estocolmo como ponto de partida para a proteção internacional do meio ambiente. Revista de Direitos Fundamentais \& Democracia, v. 6, n. 6, p. 1-25, 2009.

PEARCE, D. W.; ATKINSON, G. D. Capital theory and the measurement of sustainable development: an indicator of "weak" sustainability. Ecological Economics, v. 8, n. 2, p. 103-108, 1993.

RABELO, M. S.; LIMA, P. V. P. S. A Eficiência da inserção da variável ambiental nas instituições financeiras públicas e privadas perante o Protocolo Verde e os Princípios do Equador. REDE-Revista Eletrônica do PRODEMA, v. 3, n. 1, p. 7-22, 2009.

REIS, L. B.; CUNHA, E. C. N. Energia elétrica e sustentabilidade: aspectos tecnológicos, socioambientais e legais. Barueri: Manole, 2006.

ROBERTSON, G. P. et al. Agriculture: Sustainable biofuels redux. Science, v. 322, n. 5898, p. 49-50, 2008.

ROGERS, P. Facing the freshwater crisis. Scientific American, v. 299, n. 2, p. 46-53, 2008.

SACHS, I. O desenvolvimento enquanto apropriação dos direitos humanos. Estudos Avançados, v. 12, n. 33, p. 149-156, 1998.

SOUZA, G. H. S.; LIMA, N. C.; QUEIROZ, J. V.; PENEDO, A. S. T.; COELHO, J. A. P. M.; COSTA, A. C. S. Marketing approach of Brazilian wind energy sector. Journal of Technolog y Management \& Innovation, v. 8, n. 4, p. 46-58, 2013.

SOUZA, C. S.; MILLERD. S. O Protocolo de Quioto e o Mecanismo de Desenvolvimento Limpo (MDL): as Reduções Certificadas de Emissões (RCEs), sua natureza jurídica e a regulação do mercado de valores mobiliários, no contexto estatal pós-moderno. Revista Virtual da AGU, v. 4, n. 30, p. 1-23, 2004. 
SOUZA-LIMA, J. E. Economia ambiental, ecológica e marxista versus recursos naturais. Revista da FAE, Curitiba, v. 7, n. 1, p. 119-127, 2004.

STERLING, S. Sustainable education: re-visioning learning and change. Bristol, UK: Green Books, 2001.

TURNER, R. K. Sustainable environmental management: principles and practice. London: Belhaven Press, 1988.

UNITED NATIONS DEVELOPMENT PROGRAMME - UNDP. 2010. Available at: $<$ http://www.undp.org > . Accessed in: June 10, 2015.

WAJNBERG, D.; LEME, C. F. Exame da divulgação do relacionamento entre iniciativas socioambientais e desempenho financeiro corporativo nos bancos brasileiros. Revista de Gestão Social e Ambiental, v. 3, n. 1, p. 53-69, 2009.

WILLIAMS, O. F. The UN Global Compact: The challenge and the promise. Business Ethics Quarterly, v. 14, n. 4, p. 755-774, 2004.

WORLD HEALTH ORGANIZATION - WHO. Available at: < http://www.who.int/en/> Accessed in: June 10, 2015.

WRIGHT, C.; RWABIZAMBUGA, A. Institutional pressures, corporate reputation, and voluntary codes of conduct: An examination of the equator principles. Business and Society Review, v. 111, n. 1, p. 89-117, 2006.

Recebido em: 07 de junbo de 2014 Aceito em: 21 de dezembro de 2015 